\title{
Aesthetics of protest: An examination of the photojournalistic approach to protest imagery
}

\author{
Anastasia Veneti, Bournemouth University, UK
}

This is a preprint of ana article whose final and definitive form will be published in the special issue Rovisco, M., Veneti, A. Picturing Protest: Visuality Visibility and the Public Sphere. Visual Communication (forthcoming August 2017) All Rights Reserved. ㅇ Sage Publications, 2017.

\section{Introduction}

From Jeff Widener's 'Tank Man' in Tiananmen Square (1989) to the 'Standing Man' in Taksim Square (2013) and across coverage of the occupied squares, world news has been replete with pictures of protests and demonstrations. Such visual representations are crucial to both social movements and protesters who wish to communicate their identities and their messages to wider audiences and to the general public. Images do not merely supplement news but as Machin and Polzer (2015: 1) argue they "form part of the ideas about the world, concepts and attitudes that are communicated" and as such, they can influence public opinion (Barthes, 1981). The visual is a field where meaning is constructed and contested, as highlighted by many scholars (e.g. Machin and Polzer, 2015: 4; Doerr and Teune, 2008: 158). Placards with slogans, crowded squares, colourful tents in protest camps, close ups depicting protesters' feelings, as well as images of violent confrontations between protesters and riot police are not accidental aesthetics. Protest imagery disseminated by the mainstream media can be ideologically charged (Bolton, 1989) and therefore generate specific visualisations of power (Mirzoeff, 1998: 3-13; Campbell, 2007; Sturken and Cartwright, 2009: 21-24) visualisations that can serve to either encourage mobilisation in support of protests and the protestors' cause, or to delegitimise the protesters' causes, aims, and objectives (DeLuca and Peeples, 2002; McLeod and Detenber, 1999). 
The crucial role of the visual in contentious politics has stimulated a growing body of research, both in social movement and media studies. Such scholarly work examines multiple aspects of the visual in the repertoires of contention (Doerr, Mattoni and Teune, 2013; Mortensen, 2015). Indicatively, several studies include a focus on the visual framing of protests (Perlmutter, 2004; Corrigall-Brown and Wilkes, 2012), the use of symbols by social movements (Olesen, 2015), the impact of memes to generate public discussions (Milner, 2013) and the use of art to inform and engage with the public (Kraidy, 2016). Despite this wealth of foci, there is limited research around the role of the photojournalists in the production of protest imagery (Hattingh and Gaede, 2011). Assessing protest images requires an understanding of the processes and mechanisms that lie behind the taking of such pictures. In general, protest photos cannot be seen as entities that are independent of their creators' intentions and their aesthetic, professional and ideological criteria.

In seeking to address this lacuna, this paper offers a preliminary analysis of a wider, ongoing research project that focuses on the role of photojournalists in the production and publication of protest imagery in Greece. A fully comprehensive, in-depth examination of such phenomena could involve the exploration of various issues, including; photojournalists' political allegiances and personal beliefs (Deuze, 2005; Kim and Kelly, 2010; Hattingh and Gaede, 2011), implications of the market-oriented media environment and professional affiliations on journalistic autonomy (Dickinson and Bigi, 2009; Hardt, 1990), photojournalists' interactions with police (Newman, Simpson and Handschuh,2003), and their responses to the digital age and the concomitant emergence of citizen-journalists (Mäenpää, 2014; Andén-Papadopoulos and Pantti, 2013), amongst other topics. Although all of these factors are fundamental to the production and circulation of protest images, due to the word limitations of this paper, the current analysis focuses on questions of aesthetics that surround issues of visuality with regard to protests and demonstrations. More specifically, 
this paper examines what is photographed during a protest and how this is affected by the photojournalists' aesthetic criteria.

Scholarly work on photography (Sontag, 2008; Szarkowski, 1966) and photojournalism (Åker, 2012; Ritchin, 2013) argues that alongside the presumptions built into the accepted principle that speaks to the recording of reality, photojournalists' practice is infused with subjective language and influenced by art photographers' techniques. By relying less on the camera's documentary function, and deploying techniques typically ascribed to artistic photography, photojournalists frequently use hybridised strategies - an amalgam of documentary and artistic photography-in order to capture contemporary issues in a more nuanced way (Ritchin, 2013). As Sontag (2008:6) elucidates, in her seminal work On Photography, "even when photographers are most concerned with mirroring reality, they are still haunted by tacit imperatives of taste and conscience." Drawing on such theoretical constructs, this paper explores and discusses the impact, that these hybridised strategies employed by photojournalists, can have with regard to their visual decisions as to what is photographed and how during a protest. Finally, this paper seeks to enrich and update existing studies on protest imagery, which focus primarily on theoretical debates and visual case study analysis, by offering an empirical investigation through in-depth interviews with photojournalists.

\section{Theoretical Framework}

Objectivity, autonomy, ethics, public service and immediacy constitute the core values associated with professional journalism in democratic countries (Deuze, 2005). As a result, based on pre-existing norms, photojournalism is generally considered to be "unbiased. Factual. Complete. Attention-getting, storytelling, courageous" (Becker, 1995:6). Additionally, as Åker (2012: 327) suggests, it is the "level of authenticity" that provides the 
news image with its journalistic value. Within this context, the photojournalist's mission turns into one centred on depicting real events in the most truthful and effective way (Burnhusrt, 1994: 21). Borrowing from the definition of documentary, as being a "presentation or representation of actual fact in a way that makes it credible and vivid to people at the time" (Stott, 1973: 14), the photograph is considered a form of proof that something happened. Such definitions of photojournalism, fixed on the principle of objectivity and rooted in the 1930s (see Åker's historical account of objectivity in photojournalism), are also tied to the long history of photographs being used as evidence (Mäenpää, 2014: 92).

Despite these close links between photojournalism and objectivity and truthfulness, other factors also lie behind the taking of photographs, and thus impact upon the news photos that we consume. As they are perceived to be closely linked to values such as objectivity and truthfulness, photographs appear- at least to some extent- to carry what had been called a 'burden of truth' (Newton, 2001). A substantial body of media and communication research has provided us with important knowledge as to the professional norms guiding journalistic news work and the complex relationships that have developed between various news organisations (Gans, 1979; Cottle, 2000; Tuchman, 1978). Although photojournalists tend to "represent the world faithfully" (Machin and Polzer, 2015: 24), they do so as professionals who are aware that they need to provide images that are also saleable - often through ensuring that they address certain established news frames (Faulkner, 2013). It is as a result of such framing that mainstream media tend to cover events, such as protests, in a negative way- as a considerable number of studies on the media framing of protests and demonstrations have illustrated (McLeod and Detenber, 1999). Such negative coverage tends for example, to focus on dramatic images of violent confrontations between police and protesters and destroyed properties. As Mazzoleni and Schulz (1999: 248) argue media have turned politics into a 
"marketlike game" where the presentation of political issues can best be characterised as “"show-biz' based on battles of images, conflicts between characters, polls and marketing"; as such, avoiding meaningful debates on vital political issues, and consequently treating citizens as "passive 'consumers' of mediated politics."

This being said, despite these constraints imposed upon press photography from news organisations, "the photograph is [also] employed to fashion the world according to the intentions of the person making it [...]" (Ritchin, 2013: 7). In his analysis on objectivity, Schudson (1978) persuasively argues that any collection of facts is inevitably accompanied by their interpretations; an argument which is further enhanced by Sontag (2008: 88) who suggests that "[...] photographs are evidence not only of what's there but of what an individual sees, not just a record but an evaluation of the world." In the context of protests and demonstrations, photography can be tricky, ambivalent and highly conflictual. As various photojournalists argue, the photographing of protests is a very idiosyncratic, dynamic and inherently political process, that can become very personal and that as such it is likely to create tensions between one's own beliefs and professional guidelines (Jones, 2011; Sritharan, 2015). Without any intention of depriving photographs of their ability to reveal truths, almost everyone working with images, including those in mainstream media, are aware that "all images interpret rather than laying automatic claims to the truth" (Ritchin, 2013: 8). Photographs can only expose selective moments in the flow of reality, as chosen and defined by the photographer's intentions and skills. This is best encapsulated by the famous American photojournalist William Eugene Smith (1975), with regard to his book on the impact of mercury poisoning in the city of Minamata in Japan: "This is not an objective book. The first word I would remove from the folklore of journalism is the word 'objective' [...] My belief is that my responsibilities within journalism are two. My first responsibility is to my subjects. My second is to my readers." 
Taking a similar stance, many photojournalists have departed from the standardised conception of the photograph as 'fact' and have embarked on an exploration of "reality as a much more contested and nuanced phenomenon" (Ritchin, 2013: 17). Such endeavours have been accompanied by an experimental drive involving the incorporation of photographic techniques and styles that are usually attributed to art photography (Ritchin, 2013). These hybridised strategies employed by photojournalists resemble, to some extent, the methods developed by the New Journalism advocates. New Journalism (as identified by Tom Wolfe) was a news writing style- developed in the 1960s and 70s in which journalistic writing was entwined with literary style and as such, was characterised by a more subjective tone (Wolfe, 1972). Preceding these developments in the journalistic world, a photographic form developed in Europe during the 1920s and 1930s, shattered the established notion of 'objectivity' and challenged the main conventions of photography (Åker, 2012: 331). New Objectivity was a new photographic movement, that despite criticisms related to Russian propaganda, set out to achieve a reduction as to the 'distance' in the relationship between photographer and subject, and allowed for more artistic and nuanced representations (Newhall, 1982 [1949]: 199-216).

While these developments have had a considerable impact upon modern photojournalism, there has been only limited research on this in the fields of visual communication and journalism studies (among the most illuminating studies that have been done, are those of Ritchin, 2013 and Åker, 2012). Similarly, photographic histories have tended to adopt a rather divisive conceptualisation with regard to the documentarian and the artist, excluding overlapping and hybridised strategies, such as those mentioned above (Ritchin, 2013: 17). Nonetheless, there are few insightful studies that cogitate on the dialectic between journalistic norms and artistic creativity. Such studies draw on photojournalistic work exposed in galleries and museums (Barnhurst, 1994: 19; Newhall, 1937; Szarkowski, 1966). Perhaps the 
most striking case is that recounted by Ritchin (2013:17-18) with regard to John Szarkowski, Head of the Department of Photography at The Museum of Modern Art and director of the exhibition MIRRORS AND WINDOWS: AMERICAN PHOTOGRAPHY SINCE 1960 "in which the most interesting photographs were those that the curator could not place either in the category of art [mirrors] or documentary [windows] [...]" (cf. Szarkowski, 1978).

Galvanised by the dominant journalistic norms embedded in the media's modus operandi, and at the same time driven by their own personal beliefs and aesthetic choices, photojournalists seek to create truthful, but also interesting and beautiful images (Sontag, 2008: 6). Within this context, and despite the tension between the two photographic forms (art photography and photographic realism as used in journalism), their encounter- as illustrated by the pictures of Life and in various art exhibitions, such as the one mentioned above - is obvious in contemporary photojournalism; not only as a complementary photographic strategy in the stream of conventional news photos, but as a requirement for high quality press photography. One need only to examine those photographs that have been shortlisted for and won the most prestigious photojournalistic awards - such as Pulitzer and World Press Photo- and read the values and aims of these organisations, to understand that "accuracy" and photographic "quality of high standards" go hand in hand (World Press Photo, 2016). The aesthetic quality and the beauty of these pictures lie first and foremost in the power and the emotions that emerge through compositional choices and other aesthetic criteria. In the case of protests and demonstrations the beauty, and consequently the power, of images depicting marching crowds, violent confrontations or transient faces can be found in the "pathos" of these photos. As Sontag (2008:102) convincingly argues:

"But notwithstanding the declared aims of indiscreet, unposed, often harsh photography to reveal truth, not beauty, photography still beautifies. Indeed, the most enduring triumph of photography has been its aptitude for discovering beauty in the 
humble, the inane, the decrepit. At the very least, the real has a pathos. And the pathos is- beauty."

Sontag's words can best be exemplified by the 2015 Pulitzer Prize Winner in Breaking News Photography for their photographic coverage of the Ferguson unrest in 2014, by the staff of St. Louis Post-Dispatch (Pulitzer, 2016). Portraits of Michael Brown's relatives, violent confrontations, and the protesting crowds have been "powerful images of the despair and anger in Ferguson, MO [...] that served the community while informing the public", as described on the Pulitzer official webpage, and which won the prestigious award (Pulitzer, 2016). While such cases do not suggest that all press photography is of high artistic quality, this study argues that in an extremely competitive market, quality press photography goes beyond the established photojournalistic norms via the utilisation of hybridised photographic strategies so as to depict such phenomena in a more nuanced way. Similarly, Wahl-Jorgensen (2013), in her study of the language of award-winning journalism, argues that emotive appeals and subjective language prevail in these journalistic pieces, without however directly undermining claims to objectivity. It can be argued that in the case of photographs, it is primarily such emotional power and perceived objectivity that provides authority (Szarkowski, 1966; Barnhurst, 1994: 22).

\section{Method}

This paper draws upon empirical material from 17 semi-structured, in-depth, interviews with Greek photojournalists. The interviews were conducted in the period July 2015 to January 2016. The method was selected on the basis that such approach would allow the researcher to delve below the surface and gain a deeper understanding of participants' meanings, feelings and motivations (Arksey and Knight, 1999). The sample varied in terms of gender, 
professional affiliation, and years of employment. To secure diversity, purposeful sampling was employed and participants were recruited through the snowballing method.

The sample included freelancers, photographers in contracted positions, and stringers working for international news agencies such as Associated Press (AP), Agence FrancePresse (AFP), Reuters, the Chinese Xinhua, Bloomberg, Athens News Agency (ANS), Panos Pictures, Greek photo agencies such as Eurokinissi and SOOC, and the Greek media. Their pictures have appeared across leading publications around the world; they have participated in photographic exhibitions, and some have won prestigious photographic awards.

Since most of the photojournalists that participated in this research have covered demonstrations around the world our discussion drew on a variety of examples of protests, and were not limited to protests and demonstrations in Greece. Nevertheless, being Greek and having collaborated with the Greek media, they are all aware of how the Greek domestic media system works. In particular, the Greek media system is marked by interlocking interests among media organisations and political parties (Veneti \& Karadimitriou, 2013). According to Hallin and Mancini (2004), the Greek media system has been classified as belonging to the Mediterranean or Polarized Pluralistic model, which is characterised by strong state intervention and weaker professionalisation. More specifically, Greek media magnates transcend their media activities through trading with the political elites, by means of private and political 'businesses'; for example, with respect to the implementation of largescale state construction projects (Leandros, 2000). Ultimately, the Greek media scene can be viewed as an arena of power games, played out between different interest groups from industrial, commercial and political realms.

As this paper is part of a bigger project as mentioned above whose purpose is to expand the discussion on issues of ideology and police brutality, I have used pseudonyms for the 
participants in order to secure confidentiality. The discussion that follows is divided into two main parts that emerged from the data analysis: (a) The impact of professional norms on picture-taking and, (b) The employment of hybridized strategies.

\section{Mapping professional protest photography}

As was outlined and explained by the participants of this study, the main characteristic of any protest is that it can develop in unforeseen and unexpected ways. As Aris (Eurokinissi) explicitly argues “On paper, going at [what we consider] an 'easy' protest, you might say let's take a couple of photos and finish quickly and then this might have unexpected developments." Although this argument is unanimously supported by photojournalists, they also suggest that there are certain guidelines, some sort of 'polestar', which partly guides the photographing of protests. Concurring with relevant studies (Schultz, 2007; Mäenpää, 2014; Machin and Polzer, 2015), these guidelines constitute an amalgamation of an understanding of market demands, photojournalists' professional affiliations (especially for staff photographers) along with their personal beliefs and photographic styles.

Masters of the news game, the photojournalists have a "bodily sense of newsworthiness" and of the different kind of images that they need to produce to satisfy the needs of diverse markets (Schultz, 2007: 193). Inevitably though, this sense of newsworthiness has been influenced by the established media logic, wherein to be considered newsworthy, an event needs to satisfy set news value criteria, such as proximity, conflict, drama and personalisation (Mazzoleni and Schulz, 1999; Galtung and Ruge, 1965). Emanating from their experience and unwritten rules of practice, they explain that visual coverage of each protest should start with general shots. This initial phase of the photographing practice falls within a category described by most as, 'the news part' and follows on from their need to cover the event and provide visual information that communicates what is happening. This stage, of mainly 
descriptive images that can provide basic information about the political event, is closely tied to the entrenched principles of objectivity in journalistic practice. Claims such as: "You need to give the information" (Dimitris, freelancer), "My first concern is to depict the event" (Spiros, freelancer), "To show what is happening as first priority, who, where [...]" (George, Bloomberg), reveal their need to produce images that can be valued primarily for the information they give, as this is usually what is requested by news agencies and media outlets.

Therefore, during this first phase photojournalists are very much preoccupied with the making of 'an inventory' of images that describes the event (Sontag, 2008: 22). Such pictures traditionally address some of the classical Ws questions (Who, Where, When and Why). During the peaceful stage of a protest, pictures depict three basic elements: (a) the magnitude of the protest; (b) banners and slogans; (c) the vibe of the protest. Certainly, images of violent confrontations and arrests - where such have occurred- constitute indispensable visual material for this inventory. Reaching similar conclusions to those reached by scholars such as Altheide and Snow (1979) who have examined the commercial media logic of the presentation of politics as spectacle, all the interviewees affirmed that it is the images of violence that are the most saleable pictures, with regard both Greek and international news agencies and media outlets.

Photos of gathered and marching crowds are important as they provide information on the magnitude of the protest and as to, who participated and certain shots can even communicate the general atmosphere. Such shots are often taken from different angles, including photos taken from high buildings. As many of the interviewees explain, shots from above are not usually taken by freelancers but basically by those from the big wire agencies, that have either hired offices around the main squares where protests take place or have a whole team at the location that can cover different spots. When massive crowds are present, photos of the 
magnitude of the protest are of great importance as they provide essential visual information regarding the appeal of the protest to the public. With regard to such photos, interviewees emphasised the importance of representational fidelity, with reference to issues of digital manipulation. Despite the lack of a common set of ethical guidelines for photojournalists (Schlesinger, 2007), press photographers seem to be committed to strong ethical standards with regard to photo editing, as evidenced by the interviews conducted and relevant literature (Mäenpää and Seppänen, 2010: 460).

Subsequent to taking the pictures of the crowds, photojournalists seek to depict the causes of the protest - most commonly through images of banners and posters. Such pictures allow us, as Dimitris (freelancer) argues to "understand who protests and which their (protesters') demands are." Although photographing banners can be considered as merely part of their routine, Nondas (SOOC) argues that some protest banners and posters can be very powerful and, with the right composition, can constitute a visually stunning image. To illustrate this argument, he refers to a banner with the slogan "Fascism dies tonight" pictured during a protest in Athens on $5^{\text {th }}$ May 2010. That was part of a series of protests that have occurred in Greece following the signing of the first bailout treaty in May 2010 and the ensuing enforcement of austerity measures. The slogan possessed specific political connotations, quite similar to the key slogan during the 1973 insurgency against the military junta in Greece. Although this banner was photographed by many, Nondas argues that Tzortzinis' photo was the most captivating as he has managed to create a potent image through his choices as to composition and the embedded affective qualities (See photo WordPress, 2011).

Apart from banners, photojournalists also look for symbols which can basically serve two purposes. On the one hand, photographers who work for or with international news agencies are in need of symbols that can indicate the location of the protest, which is necessary when addressing an international audience. Manos (AP) argues, that as a foreign correspondent he 
needs to address such requirements of AP clients. He further explains that, "in my mind I have a newspaper in Oklahoma, in Indonesia, in New Zealand.” In the quest for such signs and symbols, that can indicate the location of the protest, images of flags and emblematic buildings, (e.g. the Hellenic Parliament, Wall Street, Big Ben, etc) frequently dominate the image inventory. On the other hand, photojournalists also look for symbols that can animate their photos (a way of creating interesting pictures) and at the same time communicate information about the protest. Some of the examples given by photojournalists are: people giving flowers, other performances and sketches by the protesters - such as a coffin with the flag of Europe, objects used as protest symbols like saucepans, tear gas, or Guy Fawkes masks, amongst others. Such actions and performances are very much the product of the activists, who are aware of the significance of employing visual tools so as to engage the public and the media (Mattoni 2008, Guidry, 2003). My findings concur with this view, since participants claimed that "[the protesters] know well and look for international coverage by writing the slogans in English [...], by organising happenings in order to give us, the photographers or in general the visual media, more photo opportunities [...]" (Manos, AP).

Finally, photojournalists seek to capture the vibe of the protest. Many interviewees constantly referred to the 'good protest' which, according to their arguments, is a protest that is characterised by passion, collective action and energy. As they argue, the more verve a protest has the more pictures they can take. If, by contrast, a protest is lacking in passion, they highlight the difficulty of producing interesting pictures. They were keen to explain that the dynamism of a protest should not necessarily be judged by its magnitude. In the case of a 'vibrant' protest, they wish to capture the general feeling which, in their own words, is the "passion", the "energy", the "intensity", the "action", the "combativeness" of the protest and the protesters. Such pictures usually depict protesters with their mouths open shouting slogans, raised fists, and people holding banners. As Alexis (ANS) explains "you try to 
capture [the protesters] with their mouths open. To show that they yell [...]"; and Nick (freelancer) adds: "there is a movement in their faces, at their hands when raised and this gives the intensity at the photo." In their pursuit of such images, photojournalists most frequently focus on the people in the front line, the elderly and the students. As Nick (freelancer) explains, the individuals at the front line of a protest "are the most dynamic." Their quest for more affective photos, that can manage to portray the general atmosphere, leads photojournalists to rely less heavily on casual photographic techniques and employ more diverse photographic practices.

\section{The encounter of journalistic realism and art photography in protest images}

Having completed their general shots, photojournalists move on to a second phase of photographing the protest which, according to them, is extremely demanding and challenging. The difficulty lies in the fact that they are no longer aiming for pictures that merely describe the event, but instead they are seeking to take captivating photos moving beyond the use of standard photojournalistic techniques that serve embody the narrative story of the protest. It is during this phase that most photographers tend to employ hybridised strategies mentioned above, as it is basically art photography that allows them to achieve more nuanced and multilevel depictions of the protests. Although the value of these photos derives from the norms of aesthetic evaluations (like composition, light etc), it is the affective qualities that such images possess- thanks to a more artistic and liberated approach to the photographic object- that provide their importance, in the context of protest and demonstrations.

The photographers' desire for such captivating photos is encapsulated in their claims: "I need to rack my brain for a series of photos [...]" (Manos, AP), "You are in search of a unique shot/frame" (Spiros, freelancer), "in order to be done properly, it needs to be done in an artistic way. Otherwise, you cannot communicate it. You cannot just be descriptive" (Chris, 
Reuters), "you need to attract the attention [of the reader]" (Aris, Eurokinissi), "you need to tell a story", "The important thing is to manage to delve deeper in the topic" (Nondas, SOOC). Looking at such photos, one can easily observe that there is no coherent photographic style (Sontag, 2008:88). What is photographed and how it is photographed is closely related to the personal vision of the photographers, their ability to capture the emotion and to tell the story. As Greenberg (1964) elucidates:

"This is why there are so many pictures made with documentary intent among the masterpieces of photography. But they have become masterpieces by transcending the documentary and conveying something that affects one more than mere knowledge could.[...] The photograph has to tell a story if it is to work as art."

Photojournalists who employ such hybridised strategies aim to transcend conventional forms of news photography in a quest for the exegesis rather than the mere representation of the event. Such photographers' hope to produce an aesthetic and cognitive interpretation of the event, one that departs from the conventional and stereotypical norms of news photography, and as such, one that can generate new ways of seeing and understanding. Such images may involve an unusual sensitivity, unanticipated juxtapositions, pathos, irony and visual lyricism. The central themes of these photos are usually centred on the protesters themselves. While the depiction of the vibe remains important, the focus is now shifted from the crowds to the individual(s). Photographers look for those faces and those 'moments' that enable them to depict the protesters' emotions (such as anger, frustration, sorrow, agony, happiness among others) so as to tell a story. This is usually achieved through close ups, or portraits that depict a gaze, a grimace, a body movement or a comradely assemblage. The interviewees' claims concur with Sontag's (2008: 104) argument that portraits are about "the search for 'real faces' generally sought among the anonymous," the aged, the young or extraordinary figures. As 
Manos (AP) explains, referring to a pensioners' protest in Greece, his focused on the “"biblical' figure of a black-dressed, run-down widow who protests for pension cuts. I focus on her because she is such a strong figure." In such ways, we can argue that protest imagery frequently transcends what is conventionally beautiful, seeking beauty in what Sontag (2008) has called pathos deriving from people's truths.

Furthering such arguments on the perception of beauty in protest news imagery, photojournalists endeavour to produce creative-looking pictures that depict such phenomena in a more nuanced way that can enable additional readings or signify broader ideas (Machin and Polzer, 2015:21). Such is the case of the image of the 'dancing protesters', by Marios Lolos, that became viral and generated a range of discussions (Figure 1). This picture was taken at Exarcheia in Athens, during violent confrontations between protesters and the riot police, in December 2015. The photo depicts one male and one female protester, dressed in black and wearing tear gas masks, holding each other as if they were dancing. In the light of the night's darkness, the couple stands out in the midst of the white cloud that was produced by the chemicals that had erupted on the scene. Despite the brutality of the generalised violence of the scene, the specific framing focusing on the body posture of the couple produced a series of online comments that ranged across diverse issues; from typical discussions concerning violence at protests, to those emphasising the 'subversive lyricism' of the photo. As interviewees argued and the virality of the photo suggests, this protest image managed to capture the attention of a wider audience.

\section{[Insert Figure 1]}

Figure 1. The 'dancing' protesters in Exarcheia, Athens- Greece. Courtesy of Marios Lolos $($ C Marios Lolos 
The ability to choose and create the right frame is considered pivotal in the production of a good image by all the interviewees. Many of them also discuss the difficulty of such an endeavour, especially amid violent confrontations between protesters and the police. In this context, Maria (stringer, AFP) describes a "beautiful picture" that she managed to capture in the violent atmosphere of a protest in Athens: "amid the tear gas, two persons hold a small banner featuring NO standing in front of the [Greek] Parliament [...] the NO was depicted very clearly despite the smoke in the air and it was also obvious that there was mayhem in the surrounding area". What she also notes about this picture is, that despite the obvious use of tear gas, the protesters were not wearing masks for protection. According to Maria, this picture achieves her desire to depict protesters' dissent in an aesthetically fine and with attention to the detail way.

In the course of violating the habitual rules of news photos, photojournalists also deploy symbolic devices (such as frames and composition) to create visual metaphors (Huxford, 2001:55). Following Messaris (1997:10), visual metaphors can be defined "as the representation of an abstract concept through a concrete visual image that bears some analogy to that concept." A great example of such a case is the award winning photo (2008 World Press Photo) by John Kolesidis (Figure 2). A photo with no faces, focusing on a man's hand dripping blood while holding a briefcase as he stands in front of riot police at a demonstration in Greece. Most of the photojournalists interviewed for this research referred to this photo as an example of what a good photographer is able to achieve, through an awareness of such details. As they explained, this is particularly difficult to achieve when one considers the turmoil that traditionally characterises a demonstration. This is an image abundant with symbolisms; from the wider inclusiveness of the protest to the generalised police violence. The production of this, and other complex pictures of protests and demonstrations by photojournalists, is predicated upon a conception of their role, as in significant part, as 
producers of images that can tell stories and through doing so, where possible, mobilise conscience. Similar conclusions can be found in the enlightening study of the role of photojournalists during the 1980s in South Africa by Hatting and Gaede (2011). They argue (2011:507) that "the images go beyond a news agenda and demonstrate the potential of photography to produce a powerful human document. [...] indicating a deeper understanding of the effects of apartheid and a more expressive subtle approach from the photographer [...]”.

\section{[Insert Figure 2]}

Figure 2. A man's hand drips blood as he stands in front of riot policemen during a demonstration in Athens. (C) John Kolesidis/ Reuters Pictures

A final important point, flowing from the research interviews, involves the role of freelancers as among the most prominent and vocal advocates of the hybridised photographic strategies. Liberated from some of the usual constraints that apply to staff photographers, they seek to establish their professional identity and photographic style through the employment of such techniques and novel approaches to the themes covered (Ritchin, 2013: 9). As Dimitris (freelancer) explains, with reference to an assignment he received from a magazine in Luxembourg, there are certain media that are very demanding as to the quality of the photos they require. In response to this assignment, Dimitris took black and white photos and tried to cover the topic "with an artistic approach...a focus in detail." He argues, and his comments concur with those of most freelancers in this research, that freelancers need to be "inventive" in "telling the story." In the same vein, Eleni (freelancer), while covering the conflicts and protests in Palestine, decided to cover the events by working for three months in Palestinian ambulances. She explains that she understands her role not as that of the wire photographer who needs to constantly feed the agency with a variety of photos, but rather as a 
photographer that needs to immerse herself in the events so as to tell people's stories and experiences.

As a result of the freelancers' quest for the capture and creation of captivating images, we also tend to see a more extensive use of black and white film. Driven by the freedom of being able to choose their own photographic projects, bearing in mind at the same time the economic risks that these endeavours bear for them, freelance photographers use black and white film to create distinctive photographs of protests. Ntantamis' use of such photographic practice has been mentioned by my interviewees as an example of a freelance photographer who attempts to produce audacious photographic projects. Interesting illustrations, that exemplify this photographic style, are his unflinchingly honest, candid images of protests in Athens (See Photos 3 and 4). By using black and white film Ntantamis tries to accentuate different aspects of a protest.

\section{[Insert Figure 3]}

Figure 3. Protest in Athens, Greece. Courtesy of Kostantinos Ntantamis. (C) Konstantinos Ntantamis

\section{[Insert Figure 4]}

Figure 4. Protest in Athens, Greece. Courtesy of Kostantinos Ntantamis. (C) Konstantinos Ntantamis

Although such more nuanced, artistic imagery that deviates from conventional journalistic aesthetics may not always be run by mainstream media, its aesthetic value and photojournalistic importance is acknowledged by the wider photojournalistic society (e.g. photographic awards). Thereupon, most photojournalists are interested in producing such images even if these will not be published by the mainstream media. In particular, 
photojournalists working for Greek media outlets have extensively referred to lower standards with regard to the aesthetic quality of photos in comparison to the demands by international press and newswires. They mainly attribute this to the lack of specialised photo editors in most Greek media outlets. Nevertheless, photos produced based on hybridised techniques often become viral through the utilisation of alternative forms of communication. Many of these photos are posted on the photojournalists' social media accounts, or published on blogs, or by independent media as illustrated by the practices of the participants of this study and suggested by relevant literature (Ritchin, 2013: 9-12). Once these pictures appear in public spaces they serve to contribute to wider public discussions (Mirzoeff 1998: 24).

\section{Conclusion}

In this article I have argued that the photographing of protests can be seen as flowing from an amalgamation of photojournalists' artistic predilections, working in tandem with their journalistic mission of 'bearing witness.' Picture taking during protests and demonstrations by photojournalists involves both the capturing of descriptive images that primarily feed the mainstream media's news cycle, and more complex images that seek to tell the story of those participating in such political events. Based on empirical data, this paper shows that it is through the employment of hybridised strategies -where the artistic form allows for more nuanced depictions - that powerful and audacious images of protests can be created. According to the photojournalists interviewed, the power and beauty of protest images lie in their ability to capture and transmit the pathos and the momentum of these political events. Either through focusing on individual protesters, groups of people, marches or violent confrontations, each photojournalist searches for his/her own distinctive vocabulary within photography. The use of black and white film, attention to detail and lightening, visual metaphors, colour contrasts, and audacious frames are only some of the techniques deployed 
by the photojournalists in their attempt to create meaningful, but also beautiful, images of protests.

Although this research examines the photojournalists' aesthetic criteria, and as such it does not allow us to assess the impact of such photos on the audience, various studies have indicated that the production of powerful visual representations of protests can be regarded as an important 'immaterial resource' that can potentially mobilize conscience (Doerr and Mattoni, 2007). The photojournalist has the ability to reveal a 'reality', which should not be ignored, by interweaving the information available with the artistic form to allow us seeing multiple facets of the event.

Such an examination of the encounter between art photography and journalistic realism offers an insight into the aesthetics of protests and demonstrations. Yet, as mentioned at the beginning of this paper, appreciation of other issues involved in the production of visual representations of protests are crucial to reach a comprehensive understanding of such a multifaceted phenomenon. In this context, the role of captions and the contexts in which photos are seen are also fundamental elements contributing to the potential for meaningmaking that arises. Finally, although this paper centres on picture-taking during the peaceful part of a protest, the photographing of conflict and violent confrontations between protesters and the police requires further investigation, as it is a much more complex process.

\section{References}

Åker P (2012) Photography, objectivity and the modern newspaper. Journalism Studies 13(3): 325-339.

Altheide DL, Snow RP (1979) Media Logic. Beverly Hills, CA: Sage. 
Andén-Papadopoulos K and Pantti M (2013) Re-imagining crisis reporting: Professional ideology of journalists and citizen eyewitness images. Journalism 14(7): 960-977.

Arksey H and Knight PT (1999) Interviewing for Social Scientists. London: Sage.

Barnhurst GK (1994) Photography as culture. Medien \& Zeit 1(94): 17-24.

Barthes, R. (1981). Camera Lucida: Reflections on Photography. New York, US: Hill and Wang.

Becker H (1995) Visual sociology, documentary photography, and photojournalism: It's (almost) all a matter of context. Visual Studies 10(1): 5-14.

Bolton R (eds) (1989) The Contest of Meaning: Critical Histories of Photography. Cambridge: MIT Press.

Campbell D (2007) Geopolitics and visuality: Sighting the Darfur conflict. Political Geography 26:357-382.

Corrigall-Brown C and Wilkes R (2012) Picturing Protest: The Visual framing of Collective Action by First Nations in Canada. American Behavioral Scientist 56(2): 223-243.

Cottle S (2000) New(s) times: Towards a 'second wave' of news ethnography. European Journal of Communication Research 25: 19-41.

DeLuca MK and Peeples J (2002) From public sphere to public screen: democracy, activism, and the 'violence' of Seattle. Critical Studies in Media Communication 19(2): 125-151. 
Deuze M (2005) What is journalism? Professional identity and ideology of journalists reconsidered. Journalism 6(4): 442-464.

Dickinson R and Bigi H (2009) The Swiss video journalist. Issues of agency and autonomy in news production. Journalism 10(4): 509-526.

Doerr N and Teune S (2008) Visual Codes in Movement. When the Protest Imagery Hits the Establishmnet. Available at: https://protestkuriosa.files.wordpress.com/2008/05/doerrteune.pdf (accessed 12 April 2015).

Doerr N, Mattoni A and Teune A (2013) Toward a Visual Analysis of Social Movements, Conflict, and Political Mobilization. In: Doerr N, Mattoni A and Teune S (eds) Advances in the Visual Analysis of Social Movements. (Research in Social Movements, Conflicts and Change, Volume 35) Emerald Group Publishing Limited pp.xi - xxvi.

Doerr N and Mattoni A (2014) Public Spaces and Alternative Media Practices in Europe. The Case of the EuroMayday Parade Against Precarity. In: Fahlenbrach K, Sivertsen E and Werenskjold R (eds) Media and Revolt: Strategies and Performances from the 1960s to the Present. NY: Berghahn Books, pp.386-405.

Faulkner S (2013) Images and demonstrations in the Occupied West Bank. JOMEC Journal, 1-19. Available at:

http://www.cardiff.ac.uk/jomec/jomecjournal/4-november2013/Faulkner_WestBank.pdf (accessed 20 April 2015)

Galtung J, Ruge MH (1965) The structure of foreign news: The presentation of the Congo, Cuba and Cyprus crises in four Norwegian newspapers. Journal of Peace Research 2: 65-91. Gans HJ (1979) Deciding What's News. A Study of CBS Evenning News, NBC Nightly News, Newsweek and Time. NY: Pantheon Books. 
Greenberg C (1964) Four Photographers. The New York Review of Books, 23 January 1964. Available at: http://www.nybooks.com/articles/1964/01/23/four-photographers/ (accessed 2 May 2016).

Guidry AJ (2003) The struggle to be seen: Social movements and the public sphere in Brazil. International Journal of Politics, Culture and Society 16 (4):493-524.

Hallin DC Mancini P (2004) Comparing Media Systems: Three Models of Media and Politics. Cambridge University Press.

Hardt H (1990) Newsworkers, Technology and Journalism History. Critical Studies in Mass Communication 7: 346-65.

Hattingh HMS and Gaede RJ (2011) Photographer autonomy and images of resistance: the case of South Africa during the 1980s. Visual Communication 10(4): 499-525.

Huxford J (2001) Beyond the referential. Uses of visual symbolism in the press. Journalism 2(1):45-71.

Jones J (2011) How to photograph a protest, part 3: Take great photos. In: Photography Without Borders. Available at: http://photographywithoutborders.org/blog/photojournalismguide-how-to-photograph-protests (accessed 2 May 2016).

Kraidy MM (2016) The Naked Blogger of Cairo. Harvard University Press.

Kim YS and Kelly DJ (2010) Public reactions toward an ethical dilemma faced by photojournalists: Examining the conflict between acting as a dispassionate observer and acting as a “Good Samaritan”. J \& MC Quarterly 87(1):23-40.

Leandros N (2000) The Political Economy of Media. Athens: Kastaniotis. 
Mäenpää J (2014) Rethinking Photojournalism. The changing work practices and professionalism of photojournalists in the digital age. Nordicom Review 35(2): 91-104.

Mäenpää J and Seppänen J (2010) Imaginary dark room. Digital photo editing as a strategic ritual. Journalism Practice 4(4): 454-475.

Machin D and Polzer L (2015) Visual Journalism. London, UK: Palgrave Macmillan.

Mattoni A (2008) Serpica Naro and the others. The social media experience in the Italian precarious workers struggles. Portal 5(2).

Mazzoleni G, Schulz W (1999) "Mediatization" of Politics: A Challenge for Democracy? Political Communication 16(3): 247-261.

McLeod MD and Detenber HB (1999) Framing effects of television news coverage of social protest. Journal of Communication 49(3):3-23.

Messaris P (1997) Visual Persuasion: The Role of Images in Advertising. Thousand Oaks CA: Sage.

Milner MR (2013) Pop Polyvocality: Internet Memes, Public Participation, and the Occupy Wall Street Movement. International Journal of Communication 7: 2357-2390.

Mirzoeff N (1998) What is Visual Culture? In: Mirzoeff N (eds) Visual Culture Reader. New York: Routledge, pp. 3-13.

Mortensen M (2015) Journalism and Eyewitness Images: Digital Media, Participation, and Conflict. New York: Routledge.

Newman E, Simpson R and Handschuh D (2003) Trauma exposure and post-traumatic stress disorder among photojournalists. Visual Communication Quarterly 10(1): 4-13. 
Newhall B (1937) Photography: A Short Critical History. NY: Museum of Modern Art.

Newhall B (1982 [1949]) The History of Photography. NY: The Museum of Modern Art.

Newton JH (2001) The Burden of Visual Truth. The Role of Photojournalism in Mediating Reality. New Jersey: Lawrence Erlbaum Associates.

Olesen T (2015) Global Injustice, Symbols and Social Movements. New York: Palgrave Macmillan

Perlmutter DD (2004) The anatomy of a photojournalistic icon: marginalization of dissent in the selection and framing of 'a death in Genoa'. Visual Communication 3(1): 91-108.

Pulitzer (2016) The Pulitzer Prizes: Photography Staff of St. Louis Post-Dispatch. Available at: http://www.pulitzer.org/winners/photography-staff-1 (accessed 2 April 2016).

Ritchin F (2013) Bending the Frame. Photojournalism, Documentary, and the Citizen. New York, US: Aperture.

Schlesinger D (2007) The use of Photoshop. In: Reuters. Available at: http://blogs.reuters.com/blog/archives/4327 (accessed 2 April 2016).

Schudson M (1978) Discovering the News: A Social History of American Newspapers. NY: Basic Books.

Schultz I (2007) The journalistic gut feeling. Journalism Practice 1(2):190-207.

Smith WE (1975) Minamata: Words and Photographs by W. Eugene Smith and Aileen M. Smith. NY, Holt Rinehart and Winston: An Alskog-Sensorium Book.

Sontag S (2008 [1977]) On Photography. London: Penguin. 
Sritharan B (2015) Creating the new symbols of protest imagery. British Journal of

Photography. Available at: http://www.bjp-online.com/2015/12/natalie-keyssar-

institute/?utm_source=British+Journal+of+Photography\&utm_campaign=5b30812293-

BJP_Editorial_Newsletter4_24_2015\&utm_medium=email\&utm_term=0_a74238e4ee-

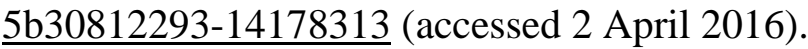

Stott W (1973) Documentary Expression and Thirties America. NY: Oxford University Press.

Sturken M Cartwright L (2009) Practices of Looking: An Introduction to Visual Culture.

Oxford: Oxford University Press.

Szarkowski J (1966) The Photographer's Eye. New York: MoMA.

Szarkowski J (1978) Press Release Mirrors and Windows. Available at:

https://www.moma.org/momaorg/shared/pdfs/docs/press_archives/5624/releases/MOMA_19

78_0060_56.pdf?2010 (accessed 2 April 2016).

Tuchman G (1978) Making News. A Study in the Construction of Reality. NY: Free Press.

Veneti A, Karadimitriou A (2013) Policy and regulation in the media landscape: The Greek paradigm concentration of media ownership versus the right to information. Management Dynamics in the Knowledge Economy 1 (3): 439-457.

Wahl-Jorgensen K (2013) Subjectivity and story-telling in journalism. Journalism Studies 14(3): 305-320.

Wolfe T (1972).The birth of the 'The New Journalism': Eyewitness Report by Tom Wolfe, New York, February 14, 1972, p. 45. Available at: http://nymag.com/news/media/47353/ (accessed 3 January 2016).

World Press Photo (2016). Available at: http://www.worldpressphoto.org/about (accessed 2 April 2016). 
WordPress (2011). Available at: https://sumzerosum.files.wordpress.com/2011/05/foties2.jpg (accessed 2 April 2016) 